Paula McClain of the University of Virginia has been appointed to the National Advisory Board for the initiative.

- Approved the proposed budget for FY 98-99.

- Approved new guidelines for re- imbursing travel costs for APSA committees and governance.

- Approved the Departmental Services Committee's plan to fund the production of a video on careers and the undergraduate study of political science.
- Approved a resolution signifying its appreciation of the benefits of the scholarly exchange between APSA and the Japanese Political Science Association and congratulating the JPSA on the occasion of its 50 th anniversary.

\title{
APSA Guidelines on External Reviews Are Revised
}

The APSA Council approved major revisions in promotion and tenure guidelines proposed by the Committee on Professional Ethics, Rights and Freedoms. The changes in Section $G$ of the Guide to Professional Ethics in Political Science deal with the solicitation and use of external letters in tenure and promotion decisions.

The Council adopted these changes after over four years of deliberation and following two surveys of the profession (see Kay Schlozman, "External Reviews in Tenure and Promotions Decisions: How Does the Process Work? How Should It?" PS, September 1998). The revised text is as follows (with new language appearing in italics):

\section{Section G: Promotion and Tenure}

32.0 External reviews are governed by a triad of rights and obligations: those of the department conducting the review; those of the candidate under review; and those of the external revicwer. All three parties share certain values; these include a commitment to fairness, dispatch, and mutual respect. But obligations and rights are not the same for all parties; each may give these values differing weight, even conflicting interpretations.
Guidelines, necessarily, must concern general principles. Guidelines for external review are not intended to be and should not be read as a uniform code to be applied to all universities and colleges alike. Academic departments differ, for example, in educational mission, institutional resources, access to external reviewers and size as well as in the administrative and legal constraints under which they operate. The proper procedure for one department or institution may not be the same for others.

\section{Rights of the Candidate}

32.1 Where external reviews are used in tenure and promotion decisions and if they are used in reappointment decisions, faculty members under review have a right to external reviews that are expert, disinterested, and timely.

\section{Obligations of the Department}

32.2 Departments and universities have an obligation to select reviewers who have appropriate professional competence, and who would provide a fair assessment of the candidate.

32.3 Departments and uni- versities are encouraged to ask candidates being reviewed to suggest names of external reviewers who know their work well, and to give the candidates under review an opportunity to call to the departments and universities' attention potential reviewers whom the candidate believes should be excluded on the grounds of personal bias.

32.4 Solicitation of outside letters of recommendation for promotion and tenure should always be phrased as an invitation recipients are free to reject. No presumption should be expressed that there is an obligation to perform service, but rather that it is a professional courtesy of assistance to the department making the request. Refusal to perform this service should not be regarded as a negative statement about the candidate.

32.5 Departments and universities should exercise restraint in soliciting external reviews because it imposes an obligation upon other scholars. Ordinarily, no more than six reviews should be solicited for promotion and/or tenure cases or senior appointments. No reviews should be solicited for decisions that do not warrant them (for example, in entrylevel and adjunct appointments, renewals of junior appointments, and special increments at the senior level).
32.6 The department conducting an external review is ordinarily obliged: [i] to provide external reviewers a copy of the candidate's curriculum vita and the principal materials on which the assessment is to be based; [ii] to ensure external reviewers sufficient time for a competent and conscientious assessment, as a rule not less than six (6) weeks; [iii] to protect confidentiality to the extent legally possible; [iv] to state whether the assessment is a confidential one, and if not, the terms of departure from confidentiality; [v] to explain to external reviewers the relative importance of external reviews to the overall review process; and [vi] to inform the external reviewers of the final decision without elaborating on the reasons for the decision.

\section{Obligations of the External Reviewer}

32.7 Once they assume responsibility for serving as a reviewer, external reviewers are ordinarily obliged: to make an assessment that is candid and fair, based solely on professionally relevant criteria and first-hand knowledge; [ii] to disclose to the department or institution conducting an external review any personal relationship with the candidate being evaluated; and [iii] to honor any deadline to which they have agreed. 


\title{
1999 \\ Ralph Bunche Summer Institute
}

\author{
Hosted by \\ the University of Virginia \\ June 6 - July 8, 1999
}

The Ralph Bunche Summer Institute invites applications from African American students between their junior and senior years of college to attend the 1999 Summer Institute. Designed to introduce 15 students to the world of graduate study and encourage application to Ph.D. programs in political science, the Institute includes two transferable credit courses, on in quantitative analysis and the other on race and American politics. In addition, guest lecturers and recruiters from Ph.D. programs visit with students, and the Kaplan Educational Center assists in preparation for taking the Graduate Record Examination. The deadline for receipt of applications is February 1, 1999.

Classes are held o the historic grounds of the University of Virginia where students have access to a fully equipped computer laboratory, library collections and other university facilities. Additionally, transportation to and from the Institute, meals, housing and course credit are provided by the University of Virginia.

Students who have participated in this program over the past nine years have reported improvement in their analytical, writing, and quantitative skills. The academic environment is challenging, yet supportive. Students learn what is necessary to be successful in a graduate program and as a scholar.

Most students who attend the Ralph Bunche Summer Institute excel in their senior year and go on to graduate school, many with full graduate fellowships and teaching assistantships. A number of Institute participants have gone on to receive their masters or Ph.D. degrees, and three have already been named assistant professors at the university level.

For more information or additional application materials, please contact:

\author{
American Political Science Association \\ Ralph Bunche Summer Institute \\ 1527 New Hampshire Avenue, NW \\ Washington, DC 20036-1206 \\ (202) 483-2512 \\ or visit our web site at: \\ www.apsanet.org
}

